\title{
UNITED NATIONS CONVENTION ON THE RIGHTS OF CHILD: FORCED CONVERSION OF HINDU MINOR GIRLS IN PAKISTAN
}

\author{
Muhammad Imran Ali \\ Department of Law Lahore Leads University Pakistan,E-mail:imran.ali@leads.edu.pk
}

(Received: October 2021; Accepted: November 2021; Published: December 2021)

\begin{abstract}
Pakistan has ratified the United Nations Convention on the Rights of Child expressing therein that the right to freedom of religion incorporates that nobody ought to be compelled to change his religion. Pakistan's constitution guarantees religious freedom to all minority communities in Pakistan. Forced conversion to Islam has become another type of rough fanaticism in Pakistan. Constrained transformation is the point at which an individual who uses pressure, power, intimidation, or danger to drive someone else to acknowledge another religion. It influences almost all minority groups in Pakistan, but the biggest victims are Hindu minor girls in Sindh province. It should be forbidden to pursue a position of power to entice vulnerable Hindu minor girls to convert under duress. As the criminal justice system in Pakistan is not addressing this issue effectively, legislation is urgently needed to protect vulnerable children. This article focuses on the need to promulgate a law providing forcible conversion of Hindu minor girls as a criminal offense. A literature review method is adopted for this paper.
\end{abstract}

Keywords: Convention on the Rights of Child- Hindu Girls-Forced Conversion-Pakistan.

\section{Introduction}

A child is raised in a family and the parents pass on their beliefs to the child, the child learns about faith while living in the family and observes his parents. The right of children to freedom of religion is the right of every child to grow freely as an independent participant in the matrix of parents, religious community and society. This means that the child has the right to freedom of religion, i.e. let him develop as a religious being.

The Convention on the Rights of the Child (CRC, 1989) is an important internationally recognized instrument on the rights of the child. Article 14 of CRC prescribes the right of the child to freedom of religion. The Convention makes it clear that governments, in particular, should not interfere with the freedom of religion of children and should encourage parents (as legal guardians) to advise children in the development of their religious beliefs and identities.

Generally, a State is distinguished by a constitutional provision that declares it an Islamic State, in an effort to promote a broader and more meaningful role for Islam in that country. This role can manifest itself in many ways and the practical consequences of a constitution declaring an Islamic state are not uniform. 
Oppression and discrimination against minorities are as old as history itself. Religious minorities are no exception to this phenomenon (Maria \& Simon, 2020). In recent years, the need for religious freedom has intensified due to the religious fanaticism of advocates of different religions. The Constitution (Constitution of Pakistan, 1973), which is intended for minorities, places great emphasis on fundamental rights.

Religious minorities are often forced to convert to Islam under great pressure. It affects almost all religious minority groups in Pakistan, but the main victims are Hindu minor girls in Sindh province (BBC, 2014). Conversion in Pakistan often involves kidnapping Hindu girls and forcing them to convert to Islam in order to get married.

After the passing of the $18^{\text {th }}$ Amendment in the Constitution (Eighteenth Amendment Act, 2010), Provinces are responsible for enacting laws. The Province of Sindh has failed to pass anti-conversion laws to protect Hindu minor girls. The criminal justice system has failed to protect underage Hindu girls from being forced to convert to Islam. Pakistan has international obligations under CRC to fulfill its obligation towards children. Forced conversion is a detestable and fierce offense and an issue that has become predominant across Sindh Province that should be eliminated by perceiving the significance of tolerance, harmony and regard for all religions and people, independent of their religion.

2. Freedom of Religion and United Nations Convention on the Rights of Child The United Nations Convention on the Rights of the Child (CRC, 1989) is a universally recognized instrument for the human rights of children. The CRC is the first universal instrument to recognize that child has rights that are highly respected in the Member States. States Parties provide special protection for children in the exercise of their rights under this Convention and submit periodical reports to the CRC Committee on their activities in the exercise of these rights. The CRC not only establishes the rights of the child but also gives children the right to seek those rights in national judicial and administrative proceedings under State administration.

According to Article 1 (CRC, 1989), a child is a person under the age of eighteen years, unless the child reaches the age of majority under the law of the concerned State. According to Article 14 (CRC, 1989), States Parties must respect a child's right to freedom of thought, conscience, and religion, subject to certain limits, such as the preservation of public safety, order, health, or morality, as well as other basic rights and freedoms. The CRC makes it clear that governments, in particular, should not interfere with children's religious freedoms and should recommend parents (as legal guardians) to help children develop their religious beliefs and identities. In addition, parents have the right and responsibility to educate the child about how to exercise 
Ali, M.I., (2021)

United Nations Convention on the Rights of Child: Forced Conversion of Hindu Minor Girls in Pakistan

their freedom of religion or belief, taking into account the changing capacities of the child. In this context, Member States recognize the right of every child to spiritual and moral development (Sylvie, 2008). The right of parents to supervise the spiritual development of their children and the right of children to practice their religious beliefs is essential. Recognition of the rights of the child to freedom of thought, conscience and religion in accordance with CRC is in line with fundamental human rights values.

Children are considered vulnerable and prone to persuasion, so the question is whether they need more protection than adults? Moreover, if children can be brought up in a religious environment by their parents, is it the duty of the State to protect children from forced conversion? The answer is that this is not a position in international law that only protects children from certain forms of abuse and conversion. In general, the State must protect the child. These include abductions, forced conversion, forced marriage, forced attendance and participation in religious rituals. States also have positive obligations to protect children from third parties and must interpret their laws to make these a criminal offense.

\section{Pakistan's Obligations to Freedom of Religion under the Convention on the Rights of Child}

Pakistan is an Islamic State with a 96.28\% Muslim population and a Hindu population of $1.60 \%$ mostly concentrated in rural Sindh Province (Bureau of Statistics Pakistan, 2021). A State Party to CRC is under obligation to apply it within its jurisdiction. Pakistan ratified the Convention on November 12, 1990 (Ali, 2018). By ratifying it, Pakistan is committed to promoting children's rights.

The position of the CRC in the national legal system of a State is an important issue for its implementation. The CRC Committee is the supervisory authority that monitors which Member States have taken steps to apply the CRC principles. The CRC Committee makes its recommendations in the light of the periodic reports from the Member States as concluding observation. In Pakistan, ratification of treaties is an executive act and legislation is needed to comply with the standards of treaties ratified by the State (Ali, 2019). An international agreement, after its ratification, can only be applied as law, after its enactment through legislation (Shehla Zia vs. WAPDA, 1994). An international agreement may not be applied in Pakistan unless the legislature passes a law addressing that treaty and provides for its enforcement within its jurisdiction.

The government's actions to implement the principles of the CRC include the rights of children enshrined in the Constitution and the list of legislation adopted in the past two years and proposed legislation. The CRC protects children under Article 14 against forced conversion, so the primary duty in Pakistan is to apply common law and amend existing laws in accordance with the principles of the CRC. Legislation

188 Sciendo Journal of Legal Studies Volume 28 Issue 42/2021 
Ali, M.I., (2021)

United Nations Convention on the Rights of Child: Forced Conversion of Hindu Minor Girls in Pakistan

addressing children was devastated by the transfer of legislative entities to the provinces following the $18^{\text {th }}$ Amendment to the Constitution in Pakistan. The advancement of Pakistan to follow the proper prerequisites is slow and in regard to enactment shielding children from the forced conversion is even slower. Pakistan is under a commitment to enact comprehensive laws that will cover the offense of child forced conversion in an extensive way.

\section{Constitutional Safeguards to Freedom of Religion in Pakistan}

The Constitution of Pakistan guarantees fundamental rights to its citizens and children. It provides the basis for the adoption of laws that guarantee and protect the rights of children. Fundamental rights are natural rights that are personal to the individual as a citizen of a free and civilized community and belong equally to every man, woman and child.

Article 9 of the Constitution provides that the State must protect all fundamental rights enshrined in the constitution, including the right to life and liberty (Constitution of Pakistan, 1973). The Constitution provides guidance to the legislature to enact laws that are necessary to protect its citizens, especially women and children. Article 9 guarantees life and liberty. Therefore, a person whose life or liberty is in any danger may claim this right as a "right to access to justice." The Supreme Court ruled that under Article 9, State is obliged to protect the lives and property of its citizens by law against all violations (Watan Party vs. Federation of Pakistan, 2011). The Supreme Court also established the principle that the word life includes all means that are constitutionally and legally available to a person born in a free and dignified country (Ali Imran vs. Forest Wildlife and Fishery Department, 2020). The right to life is guaranteed by the nature of the constitution. Article 9 included the right to live in a world filled with a wide diversity not only of the present generation but also of their descendants.

Article 25 of the Constitution guarantees citizens equal justice and equal legal status (Constitution of Pakistan, 1973). There are three clauses in this Article. The first clause is about equality. The second clause prohibits discrimination based on sex. The philosophy of this clause is that gender discrimination is very common in Pakistan. The third clause refers to an exception as a special provision for children and women. Clause three regulates the rest of Article 25, which provides that nothing in this Article shall prevent the State from enacting laws for the protection of women and children. Article 25 (3) recognizes the special right to protect children due to their vulnerability. It also allows the State to pass laws to protect women and children. The Supreme Court concluded that the assumption in Article 25 (3), that the State adopts special provisions for the protection of women and children, means 
Ali, M.I., (2021)

United Nations Convention on the Rights of Child: Forced Conversion of Hindu Minor Girls in Pakistan

not only the protection of the body but also the extension of the rights of women and children (Fazal Jan vs. Roshan Din, 1992).

Article 20 of the Constitution plays an important role in protecting religion (Constitution of Pakistan, 1973). In this context, the meaning of Article 20 is not limited to matters of faith. It also applies to acts done in pursuance of 'religion' and, therefore, includes the guarantee of rituals, ceremonies and moods of worship that are an integral part of religion. What is an essential part of religions as religious practices must be decided by the courts, based on the doctrine of a particular religion and encompassing those practices that the community considers part of its religion. The phrase "freedom" meant not only freedom from unlawful bodily constraint, but also freedom of association, thinking, religion, belief, and emotion. However, the State was granted the power to regulate someone who causes harm to others (Ghulam Mustafa vs. Judge Family Court, 2021). The right to spread a faith means the right to pass on one person's beliefs to another or to set out the principles of that belief but does not include the right to convert another person into the former's beliefs. Of course, the latter is free to accept another religion but no one has the fundamental right to convert him to another religion if he does not do so of his free choice.

Supreme Court observed that a reading of Article 20 of the Constitution reveals that the right to profess religion and administer religious institutions is multi-layered. Freedom of religion guaranteed in Article 20 must be freely interpreted and include freedom of conscience, thought, expression, belief and faith. Freedom, independence of the individual are fundamental to liberal democracy and individual freedom based on religious freedom should not be restricted by applying the interpretation of the law solely to religious beliefs and practices such as social freedom. Supreme Court explains the distinction between the two categories of rights protected in Article 20 sub-paragraphs (a) and (b), namely individual and community rights (Suo Moto Case, 2014).

Freedom of religion is guaranteed to "all citizens of the country," regardless of their age and religion. The right to religious conscience does not distinguish between majority and minority or Muslims and non-Muslims. By its very nature, it is a "guarantee of equal protection" granted to every citizen, every religious community and every sect. The right to profess and practice religion is granted to all citizens. Neither the majority religious groups nor minority religious groups can impose their religious will on the citizens. As a result, it not only protects each other's religious values but it also protects all citizens against the religious beliefs of their fellow believers.

It is obvious from the above conversation that the Supreme Court to be sure went to extraordinary subtleties to clarify that an individual has a privilege to practice his or her religious belief in understanding to their conscience as the person is in no way bound by the dominant view of his religious denomination. Moreover, a community

190 Sciendo Journal of Legal Studies Volume 28 Issue 42/2021

ISSN 2457-9017; Online ISSN 2392-7054.

Web: publicatii.uvvg.ro/index.php/jls. Pages $186-201$ 
whatever religion it acknowledges has a right to practice its religious faith and has a right to maintain its religious institutions. The right to spread a faith means the right to pass on one person's beliefs to another or to set out the principles of that belief but does not include the right to convert another person into the former's beliefs. Of course, the latter is free to accept another religion but no one has the fundamental right to convert him to another religion if he does not do so of his free choice (Ghulam Mustafa vs. Judge Family Court, 2021).

\section{Penal Laws Addressing Religion in Pakistan}

The Pakistan Penal Code (PPC, 1860) provides punishments for all offenses charged in Pakistan. The PPC is the law of crimes of the land. Chapter XV of the PPC contains provisions on religious crimes. These crimes can be divided into three broad categories; desecration of places of worship, resentment or attack on the religious feelings of people, obstruction of religious gatherings. Section 295 (PPC, 1860) states that anyone who destroys, damages, or contaminates a place of worship or an object attributed to a particular category of persons for the purpose of insulting the religion of a particular category of persons, or knowing that a category of persons may treat such destruction as an insult to their religion is punishable by imprisonment up to two years or fine or with both. According to Section 295-A (PPC, 1860), anyone who consciously and maliciously intends to insult the religious feelings of any class of citizens with visible words, records, or images, insults the religion or belief of that class is punished with imprisonment of up to ten years or with fine or both. Section 296 (PPC, 1860) states that anyone who intentionally disturbs any assembly lawfully worshiping religious services is punishable by up to one year's imprisonment or with a fine or both. Section 297 (PPC, 1860) provides that anyone who harms a person's feelings or offends the faith of a religious community, or insults a human corpse, or those gathered at a funeral, shall be punished by imprisonment for a term of one year or with a fine. According to Section 298 (PPC, 1860), anyone who in order to offend a person's religious feelings, utters any word or hears it or makes a gesture in his eyes is punishable by imprisonment for up to one year or with a fine or both. According to Section 295 and 297 (PPC, 1860), it is illegal to enter, damage, or defile a place of worship or objects by a particular category of persons with the intent to insult another person's religion. Section 297 extends the principle of Section 295 to cemeteries and those intended for burial rites. It provides punishment for those who break the law at places of worship, cemeteries, or funerals. Section 295A provides penalties for insulting the religious feelings of any class by insulting their religion or belief. In 2017, the Criminal Law Amendment Act was approved. The amendment adds a proviso to Section 498-B of the Pakistan 
Ali, M.I., (2021)

United Nations Convention on the Rights of Child: Forced Conversion of Hindu Minor Girls in Pakistan

Penal Code, making the forced marriage of a juvenile and non-Muslim woman a crime punishable by five to ten years imprisonment and a fine of 500,000 rupees.

These laws are general in their application and do not provide protection against forced conversion. Pakistan Penal Code does not contain any provisions aimed at preventing conversations from one religion to another using violence, deception, incitement, or persuasion. The mechanism to achieve these goals is silent in PPC. Forced conversion is a major issue in Pakistan and was not tended to viably in PPC. There is an absence of enactment that characterizes forced conversion.

\section{Forced Conversion of Hindu Minor Girls in Pakistan}

According to the Sindh Child Protection Authority Act, 2011 child means a person who has not attained the age of eighteen years. Forced conversion of Hindu minor girls is not a new issue in Pakistan. In the last few months, there have been reports of forced religious conversion of Hindu girls abducted in Sindh, who later married their abductors (Gandhara, 2021). According to news reports, a dozen cases of minor Hindu girls falling victim to such atrocities were recorded during the first quarter of 2021(Express Tribune, 2021). About 20 Hindu girls are abducted every month, converted to Islam and forced to marry their abductees in Pakistan (Universal Periodic Review of Pakistan, 2017).

Forced Conversion of minor Hindu girls is not a new problem. The Pakistan Hindu Council filled a constitutional petition in the Supreme Court of Pakistan pleading therein for the protection of minor Hindu girls from forced conversion through abducting and forced marriage by Muslim men in 2007 (The Pakistan Hindu Council vs. Pakistan through Ministry of Law, 2007).

Article 20 (Constitution of Pakistan, 1973) gives a citizen the right to spread his religion but this right does not include the possibility for anyone to convert a person to another religion by force or indictment. Forced conversion or the imposition of beliefs on others tends to violate the right to freedom of religion.

Forced conversion to Islam has become a form of violent extremism in Pakistan. Forced conversion is defined as when someone presses, forces, patiently, or threatens to persuade another person to follow another faith. Most minority groups in Pakistan are affected, but Indian girls in Sindh province are most affected. Most minority groups in Pakistan are affected, but Hindu minor girls in Sindh province are more vulnerable. Conversion to Islam is a one-way street. If a person is forcibly or voluntarily converted to Muslim, the return will be an act of apostasy punishable by death under Islamic Law. The person cannot return due to the imminent danger of death. There is no way for a person to return to his faith because of the imminent danger of death. Forced conversion occurs when some physical, emotional, or psychological violence is used to ensure religious conversion. Thus, victims of forced conversion are usually abducted and transformed by violence, coercion, or

192 Sciendo Journal of Legal Studies Volume 28 Issue 42/2021 
threats, forced to choose to accept another religion or faith. Violence is generally not only directed against the victims but is used and threatened by their relatives.

Although forced religious conversion complements another layer of violence, there is ample evidence that a sophisticated system of violence against girls exists within recognized social normative structures. The system is deliberately supported by coordinated action and State negligence. Although the emergence of children and forced marriages are a moral and legal imperative of the State, accountability for these crimes has too often been the exception.

\section{Methods of Forced Conversion of Hindu Minor Girls}

While there are particular methodologies used to constrain individuals to forced conversion, two regular sorts are bonded labor and forced marriage in Pakistan (Modern Slavery in Pakistan, 2019). Most bonded laborers in Sindh belong to the Hindu minority, essentially having a place with the Scheduled Castes. Bonded laborers are oppressed because of debts utilizing their labor as a type of installment and staying underneath reconnaissance. Even in cases where men and women were enslaved as a result of religious hatred. When they work in agriculture, brick kilns, tanning and carpets, they are usually exposed to physical and sexual viciousness. Government authorities neglected to uphold the country-wide guideline on bonded labor abolition while police repeatedly fails to lodge FIR's against landlords. Three components save this pattern: social acknowledgment of the marvel i.e. customary tyrant and progressive rustic culture, weakness because of extreme destitution and imbalance, and the impact of powerful landlords, which influence countrywide administration and politicians.

The occurrence of revealed instances of Hindu minor girls being compelled to wed Muslim men and convert to Islam because of their marriage has incredibly expanded. After forcefully converting, young ladies are frequently denied to meet their families. Those who manage to return to their families are seen as traitors to the faith, which means persecution. Sindhi Hindu minority's helplessness to constrained conversions is connected among various components to social and financial weakness like destitution and social distance. Minorities lacked schooling, occupations and faced social distance. In addition, conservative Muslim groups influence local government structures to maintain and stabilize discriminatory practices against non-Muslim communities, and severe misogyny and patriarchy affect women's minorities even more than others' access to education and the labor market.

\section{Causes of Forced Conversion of Hindu Minor Girls}

Religious organizations assume a critical part in keeping up with the norm, forestalling the making of a particular lawful structure for forced conversion and 
Ali, M.I., (2021)

United Nations Convention on the Rights of Child: Forced Conversion of Hindu Minor Girls in Pakistan

restricting the activities of the police and judges when a case is accounted for. To support the conversion, they are registered at local shrines. However, most religious organizations have no doubt about the nature of conversion and false information provided by the abductor is widely acknowledged. Certificates issued by these authorities become official documents, and the law gives them credibility to justify violations during investigation and trial.

To report a forced conversion, the victim's family or person comes to the police station and records the first information report (FIR). Police statements were not always accurate, especially when community members were involved. In some cases, the police also refuse to register the FIR, so the families of the victim girls rarely recourse against the assaulters. In cases where police file their reports, the courts generally did not decide custody of the girls, even though the girls were 12 or 13 years old. Therefore, it is clear that political power or traditional sympathies limit the work of the police. As a result, religious minorities were isolated from the community and emigrated from Pakistan. During the process of prosecution and evidence, the girl remains within the custody of the culprit of the forced conversion, which makes it easier to testify in his favor because she is afraid of ongoing pressure and physical retaliation. Many families have chosen not to denounce the death threats of influential criminals.

In 2016, the CRC Committee issue guidance on forced conversion and forced marriages. The Committee showed its concern that forced conversion of non-Muslim girls and forced marriages to continue to practice in Pakistan. It is particularly worrying that Islamic Ideology Council has blocked law enforcement efforts to prevent forced conversion in Pakistan. The Committee recommends that Pakistan prohibits forced conversion of a person who would be expelled from faith without his or her consent (CRC Committee Concluding observations, 2016).

\section{Legislation Addressing Forced marriage of Hindu Minor Girls in Sindh}

According to Child Marriage Restraint Act, 1929, it is a marriage that is accomplished before reaching the age of majority in Pakistan, which is eighteen years for men and sixteen years for women. This Act prohibits child marriages under Sections 4, 5 and 6, the main purpose of the law is to restrict the validation of child marriages and it applies to all classes of people in Pakistan. Prior to the Eighteenth Amendment to the Constitution, this Act was a legal instrument to regulate child marriage in Pakistan. Now legislation is a Provincial subject.

After the $18^{\text {th }}$ Amendment in the Constitution, the issue of family law enactment was delegated to the Provinces. Sindh is home to the majority of Pakistan's Hindu population. The Sindh Hindu Marriage Registration Act, 2016 made Sindh the first province in Pakistan to adopt legislation allowing Hindu and other non-Muslim weddings to be registered. 
Hindu girls and women have lived in the consistent dread of being abducted, compelled to leave their faith, convert and wedded to somebody outside their religion. It is the obligation of the state to give a wide range of assurances to minority bunches including Hindus from a wide range of barbarities dispensed to them and guaranteeing they partake in similar rights as others in the country.

The issues looked at by Hindu ladies exhibit the critical requirement for successful enactment on the subject. Before the enactment of this Act, no specific legitimate system existed in the law to enroll a Hindu marriage. The Hindu people used to get their marriages registered with the assistance of rules present in the Special Marriage Act 1872. This created problems with identification documents travel documents and transfer of property. This Act fills in as an achievement for Hindus due to its most significant system for the registration of Hindu weddings, which covers the terms on which the marriage may be contracted, the processes for dissolving the marriage, and the basis on which the marriage may be dissolved. Marriage certificate is provided under Schedule A of this Act Section 4 of the Act specified that a marriage might be solemnized under this Act if the accompanying conditions are satisfied, in particular; parties to the marriage are of 18 years old or above, parties to the marriage offer their free consent, are not in a prohibited level of relationship, do not have a spouse living at the time of marriage, and at least two witnesses are present at the moment of marriage validation and registration. The marriage registration paperwork may now aid Hindus in proving their marriage at whichever moment it expects them to, and will obviously benefit Hindu women by reducing the number of coercive weddings, rape, kidnapping, and forced religious conversions.

\section{Causes of Failure to Stop Forced Conversion of Hindu Minor Girls}

Not only are there minorities' reliable complaints about forced conversion, but these conversions and other offenses are difficult to prove in courts because of the concealed nature of the offense. Religious discrimination and lack of proper criminal justice dealing with forced conversion are the main causes of failure. Pakistan's minority girls and women have to deal with coherent and systematic violations of the phenomenon of forced conversion, violations of the rights guaranteed by the Pakistani constitution and international human rights law. Forced conversion is often used to conceal other crimes, such as sexual and physical violence, kidnappings, abduction and rape.

\subsection{Lack of Proper Legislation}

Legal definitions provide the framework for adjudicating, specifying the criteria which need to prove the accused guilty of an offense. Pakistan Penal Code does not provide a definition for forced conversion. Existing laws and legal frameworks are 
Ali, M.I., (2021)

United Nations Convention on the Rights of Child: Forced Conversion of Hindu Minor Girls in Pakistan

inadequate, there is an urgent need for a concrete and binding law. The government at the time did not understand the seriousness of the matter and ignored the call for stricter and more specific laws addressing the subject.

\subsection{Failure of Law Enforcement Agencies}

In most cases, the police are unwilling or unable to comply with their duty to protect minorities. Personal religious beliefs or connections with strong local religious groups involved in forced conversion cases mean that the police are not investigating properly which resulted in failure to rescue the abducted girls. It is necessary to ensure a faster response time in case of abductions that includes fair reporting and prompt registration of FIR and that the police give security to girl victims and their families who are threatened by abductors. This requires independent, effective, responsive and accountable complaint procedures.

The Pakistani police are dealing with shortcomings in many areas including equipment, technology, personnel, training and technical skills. In addition, there is a lack of policy requirements to address these issues. Apart from the public inconvenience, the police high officials do not seem to feel any responsibility for the society they are supposed to serve. Police officers who have been exposed to serious violence are almost never prosecuted because the legal system is designed to protect police officers from accountability.

\subsection{Poor Police Investigation}

The first step in reporting forced conversions is FIR registration, victim retrieval and recording of her statement. Police sometimes create obstacles for victims in these cases. Families of victims often complain that statement of the victim recorded by police containing accusation is not based on facts, especially when prominent members of the community are involved. Police also sometimes deny the victim's right to register an FIR. This leads to feelings of helplessness among the family of the victim and reduces their motivation to proceed. Police declined to investigate the nature of the suspicious circumstances of forced conversion or to meet with the girl's parents. Article 164 of Code of Criminal Procedure, 1898 (CrPC) requires a Judicial Magistrate to record the victim's statement in his judicial capacity. However, in cases where the police have already registered a statement, this procedure is generally not followed. In addition to apathy, due to the inequality of social and political power structure, the police can also have a significant influence on facilitating or building up immunity for criminals.

\subsection{Mixed Approach of Judiciary towards Forced Conversion Cases}

Courts have a mixed history of protecting minority religious rights. Although the High Courts have made some fundamental decisions, such as deception or neglect 
of minority religions in terms of conversion, some courts have delivered countermajoritarian judgments that have quelled a lawmaking body's endeavors to condemn this practice. For instance, in Pakistan Hindu Council vs. Pakistan through the Ministry of Law, the Supreme Court has held that the applicant had filed the current constitutional petition with the supplication that for the protection of fundamental rights of the citizen, the Supreme Court may guide the Government to enact a law endorsing it to be an offense culpable with detainment for an individual who converted or attempted to convert any individual from one religion over then onto the next by utilization of forcer, allurement or by fake means or supported or abetted any such forced conversion. The Supreme Court has held that in the presence of Article 20 of the Constitution, there is no need for specific legislation as had been applied for, in light of the fact that each citizen had a fundamental right to proclaim, rehearse and engender his religion. Supreme Court has dismissed the petition with the observation that where there was a forced conversion, the law consistently took its course.

\subsection{Mob Intimidation in Courtroom}

The Courts before which such cases are fixed additionally go under massive pressing factors when hearing cases identifying with forced conversion. By and large, when a girl is brought before the court to confirm whether she has converted willingly, the courtroom is crowded with people chanting slogans for such conversions. People sometimes celebrate the "conversion" of a girl outside the courtroom.

\subsection{Threats to Victim}

Most cases of forced conversion do not lead to coordinated assistance to the victims of this crime. the abductor often files a counter FIR against a girl's family members or takes legal action on allegations that the girl's family is harassing the girl who has been intentionally converted married to an abductor.

The reason these cases often go away is because the victim is always threatened to record her statement in favor of the abductor' These victims are normally mishandled and threatened to give statements in favor of abductors or face further maltreatment and savagery against them and their families. The biggest problem in these cases is that the victim is often left under the custody of the abductor during the proceedings and, therefore, the victim has no choice except to testify in his favor. It is important to mention here that many girls who are victims of such situations realize that their re-acceptance in their family, social culture social and is not easily possible, therefore, do not want to further defame their families. 
Ali, M.I., (2021)

United Nations Convention on the Rights of Child: Forced Conversion of Hindu Minor Girls in Pakistan

\subsection{Influential Religious Leaders}

Pakistan is a very religious entity and, as summarized above, even a sufficient number of religious leaders can block legislation.

\section{Need for a Specific Anti-Forced Conversion Law in Sindh}

There are social circumstances where the law must be particularly strict in terms of both punishment and prosecution. Immediate arrest, difficulties in obtaining bail, rules that increase the responsibility of police and prosecutors, special courts and immediate compensation for victims are some of the measures often enshrined in special laws. To ensure justice for the victims of forced conversion, the government must take adequate measures to enact the Protection from Forced Conversion Act. Several reforms should be needed in cases of forced conversion in Pakistan. Effective legislation and comprehensive laws are acceptable signs that the government has recognized the problem and has responded appropriately.

Laws can be used to protect deprived groups from those who have been subjected to coercive conversion, and the correct application of these rules can be a countermeasure. Although these general laws exist, special religious enforcement laws must have a religion to prevent potential harm rather than to protect many religions from the suspicion of a minority threat. Despite the existence of these general laws, specific forced conversion laws should serve a non-religious purpose to protect potential victims rather than protecting the religious majority group from alleged threats from religious minorities.

In addition, a good anti-conversion law should focus on the rehabilitation of victims and limit the complaint process and not allow for the prosecution of someone who has witnessed the victim's conversion. But even well-designed and enforced laws require police, judges, and government agencies to enforce these laws in a nondiscriminatory way.

A revised version of the Protection of Minorities Bill was presented in the Sindh Assembly in 2019. Once more, religious groups arranged a protest, contending that the government was making obstructions for willing proselytes for the sake of securing minorities (Dawn, 2019). The proposed bill provides the age of the majority. No individual will be considered to have changed his religion until achieving the age of majority. Any minor who professes to have changed his religion prior to achieving his majority will not be considered to have changed his religion and no action will be taken against him for any such case or action made by the minor. No parent or guardians of the minor decide to change the religion of the family. This Bill characterizes that forced conversion implies compelling an individual to embrace another religion under pressure, power, compulsion or danger or any coercion, force or threat that may be directed against a victim's family, loved one, community or property. A forced conversion can occur through various modes

198 Sciendo Journal of Legal Studies Volume 28 Issue 42/2021

ISSN 2457-9017; Online ISSN 2392-7054

Web: publicatii.uvvg.ro/index.php/jls. Pages $186-201$ 
Ali, M.I., (2021)

United Nations Convention on the Rights of Child: Forced Conversion of Hindu Minor Girls in Pakistan

which will incorporate yet not be restricted to marriage, bonded labor. This Bill provides punishment for forced conversion by stating that any individual who forcefully converts someone else will be liable to imprisonment from five years to life imprisonment and a fine payable to the victim.

The law doesn't permit forced conversions essentially but at present, the law is regularly influenced especially on the pretext of religious conversions. Attempts by members of the Sindh Assembly to pass laws on the protection of minorities stand fizzled and legislation in the Provincial Assembly has not yet been passed.

\section{Conclusions}

Countries that want to protect citizens from forced conversion have options under constitutional and international law. The child has the right to protect himself from family and religious organizations for freedom of choice, religious conversion, or for religious purposes. The CRC Committee must pay close attention to freedom of religion, fundamental rights that are strictly respected. The Committee should use its resources for any violation of religious freedom.

Not only are there minorities reliable complaints about forced conversion, but these conversions and other offenses are difficult to prove in courts because of the concealed nature of the offense. Religious discrimination and lack of proper criminal justice dealing with forced conversion are the main causes of failure. Pakistan's minority girls and women have to deal with coherent and systematic violations of the phenomenon of forced conversion, violations of the rights guaranteed by the Pakistani constitution and international human rights law. Forced conversion is often used to conceal other crimes, such as sexual and physical violence, kidnappings, abduction and rape.

The impunity of perpetrators is reflected in media reports and data collected by civil society organizations. The Court's judgments in some cases confirmed these findings. Subsequent Pakistani governments have failed to face this challenge. Therefore, in order to respect religious diversity, the rule of law and human dignity and universal human rights, it is essential that the federal and provincial governments of Pakistan take steps to stop forced conversion.

Forced conversion has been created, advanced and proliferated with no reasonable premise and is pursuing the Islamophobic political objective of defaming the state and society of Pakistan and all the more especially the religion and religious characters in it. We must understand that a particular branch of law can never be selfsustaining, laws must be developed and evolve with the need of the hour, and a strict and independent law against forced conversion is the most urgent need of the time. Existing laws and legal framework are inadequate, there is an urgent need for a 
Ali, M.I., (2021)

United Nations Convention on the Rights of Child: Forced Conversion of Hindu Minor Girls in Pakistan

concrete and binding law. The government at the time did not understand the seriousness of the matter and ignored the call for stricter and more specific laws.

\section{Acknowledgments}

The author thanks the anonymous reviewers and editor for their valuable contribution.

\section{Funding}

This research received no specific grant from any funding agency in the public, commercial, or not-for-profit sectors.

\section{Author Contributions}

The entire article was written by Muhammad Imran Ali.

\section{Disclosure Statement}

The author has not any competing financial, professional, or personal interests from other parties.

\section{References}

1. Arshad Mahmood vs. Govt. of Punjab, (2005). PLD Supreme Court 193.

2. Ali Imran vs. Forest Wildlife and Fishery Department, (2020). PLD Lahore 24.

3. Ali. M. I., (2018). Protection of children from sexual abuse in early years education in Pakistan: Challenges and Issues, Journal of Early Childhood Care and Education, 2, 113 134.

4. Ali, M. I., (2019). Protection of Children from Sexual Abuse: Application of the United Nations Convention on the Rights of the Child in the Domestic Legislation of Pakistan \& India, NIU International Journal of Human Rights, 6, 29-52.

5. Arshad Mahmood vs. Govt. of Punjab, (2005). PLD Supreme Court 193.

6. Bureau of Statistics Pakistan, Population by Religion.

7. Code of Criminal Procedure, (1898).

8. Convention on the Rights of the Child, (1989).

9. Constitution of the Islamic Republic of Pakistan, (1973).

10. Constitution (Eighteenth Amendment) Act, (2010).

11. CRC Concluding observations on the fifth periodic report of Pakistan, (2016). https://tbinternet.ohchr.org/ layouts/15/treatybodyexternal/Download.aspx?symbolno=CR $\mathrm{C} \% 2 \mathrm{fC} \% 2 \mathrm{fPAK} \% 2 \mathrm{fCO} \% 2 \mathrm{f} 5 \& \mathrm{Lang}=\mathrm{en}$ (Accessed 29 October 2021).

12. Fazal Jan vs. Roshan Din, (1992) PLD Supreme Court 811.

13. Ghulam Mustafa vs. Judge Family Court, (2021) CLC 204.

14. Maria, M., Simon, W. F., (2020). Religious Minorities in Pakistan: Identities, Citizenship and Social Belonging, South Asia: Journal of South Asian Studies, 43 (1), 52-67.

15. Pakistan Penal Code, (1860). 
United Nations Convention on the Rights of Child: Forced Conversion of Hindu Minor Girls in Pakistan

16. Pakistan Hindu Council vs. Pakistan through Ministry of Law, (2012) P L D Supreme Court 679.

17. Pakistani Religious Minorities Protest Forced Conversion of Girls,(2021). Gandhara. https://gandhara.rferl.org/a/islamabad-protest-religious-conversions/31405032.html (Accessed 29 October 2021).

18. Shehla Zia vs. WAPDA., (1994) PLD Supreme Court 693.

19. Sindh Assembly urged to reject forced conversion bill, (2019). Dawn. https://www.dawn.com/news/1479291 (Accessed 30 October 2021).

20. Stories of forced conversion to Islam in Pakistan, (2014). https://www.bbc.com/news/av/world-asia-29008267 (Accessed 30 October 2021).

21. Suo Moto Case SMC No.1, (2014). PLD 2014 Supreme Court 699.

22. Sylvie, L., (2008). Children and Religion under Article 14 UNCRC: A Critical Analysis, International Journal of Children's Rights, 16 (4), 475-504.

23. The Pakistan Hindu Council vs. Pakistan through Ministry of Law, (2007). Constitutional Petition No. $70-\mathrm{K}$.

24. Two Hindu girls forcibly converted, (2021). The Express Tribune. https://tribune.com.pk/story/2288979/two-hindu-girls-forcibly-converted (Accessed 29 October 2021).

25. Universal Periodic Review of the Islamic Republic of Pakistan to UN Office of the High Commissioner for Human Rights for the consideration of the 3rd Universal Periodic Review of the Islamic Republic of Pakistan. https://www.hrw.org/news/2017/03/30/submissionuniversal-periodic-review-pakistan (Accessed 29 October 2021).

26. CRC Concluding observations on the fifth periodic report of Pakistan, (2016). https://tbinternet.ohchr.org/_layouts/15/treatybodyexternal/Download.aspx?symbolno=CR $\mathrm{C} \% 2 \mathrm{fC} \% 2 \mathrm{fPAK} \% 2 \mathrm{fCO} \% 2 \mathrm{f} 5 \&$ Lang=en (Accessed 28 October 2021).

27. Watan Party vs. Federation of Pakistan, (2011). PLD Supreme Court 997.

28. Universal Periodic Review of the Islamic Republic of Pakistan to UN Office of the High Commissioner for Human Rights for the consideration of the 3rd Universal Periodic Review of the Islamic Republic of Pakistan. https://www.hrw.org/news/2017/03/30/submissionuniversal-periodic-review-pakistan (Accessed 29 October 2021). 